Original Research Article

\title{
A study to evaluate prescribing pattern and cost minimization analysis of antihistamines among patients of allergy
}

\author{
Ayesha Vaseem ${ }^{1}$, Mazher Ali $^{2}$, Md. Mustafa Ali Khan
}

\begin{abstract}
${ }^{1}$ Department of Pharmacology, DCMS, Hyderabad, Telangana, India

${ }^{2}$ Department of Psychiatry, DCMS, Hyderabad, Telangana, India
\end{abstract}

Received: 26 August 2016

Revised: 28 August 2016

Accepted: 28 September 2016

*Correspondence to:

Dr. Ayesha Vaseem,

Email: drayeshamazher@

gmail.com

Copyright: () the author(s), publisher and licensee Medip Academy. This is an openaccess article distributed under the terms of the Creative Commons Attribution NonCommercial License, which permits unrestricted noncommercial use, distribution, and reproduction in any medium, provided the original work is properly cited.

\begin{abstract}
Background: Allergy is a hypersensitivity disorder of the immune system of the human body. In this study we selected CMA, It evaluates the cost differences between two or more medication from one group and with a similar clinical effect and then determines the least costly alternative. This helps in making best possible decision ensuring the maximum available benefits from every penny spent to achieve reasonable value for money.

Methods: This prospective observational study was conducted to assess the prescribing pattern and cost minimization of antihistamines in patients of allergy in a tertiary care teaching hospital. 210 outpatient and inpatient prescriptions of patients coming to tertiary hospital during the period July 2015 to July 2016 were studied and the most commonly prescribed antihistamines identified and their cost different between branded and generic versions analysed.
\end{abstract}

Results: Most commonly prescribed antihistamine is cetrizine followed by levocetrizine and fexofenadine.

Conclusions: This study demonstrated a significant price difference, ranging from $4 \%$ to $83.75 \%$ between the branded and generic version of given drugs. This in turn is leading to an increase in the cost of total treatment.

Keywords: Antihistamines, Cost minimization analysis, Prescribing pattern

\section{INTRODUCTION}

Allergy is a hypersensitivity disorder of the immune system of the human body. It occurs when a person's immune system reacts abnormally to normally harmless substances, present in the environment. ${ }^{1}$ It includes a number of disease conditions like hay fever, food allergies, atopic dermatitis, allergic asthma, allergic rhinitis and anaphylaxis. ${ }^{2}$

Allergy is a major global health issue. There has been surge in allergic diseases in India in terms of prevalence as well as severity. Approximately $20 \%$ to $30 \%$ of total population suffers from one or more allergic diseases in India. ${ }^{3,4}$

The World Allergy Organization (WAO) has warned that Growing industrialization, declining biodiversity pollution due to urbanization, household environmental tobacco smoke (ETS) exposure coupled with sedentary lifestyles have been associated with increased surge in allergic diseases, especially among children in the developed and developing country. ${ }^{5}$ It is believed that by 2050 about 50 percent of all children will suffer from some sort of allergies.

A study done in 1964 showed the prevalence of asthma was $1 \%$ and allergic rhinitis was $10 \%$ respectively in the country. ${ }^{6}$ Later new data reported that about $15 \%$ people suffer from asthma, and over $20 \%$ are suffering from allergic rhinitis. ${ }^{6}$

A multi-centre population study, Indian Study on Epidemiology of Asthma, Respiratory Symptoms and Chronic Bronchitis (INSEARCH) covering 12 centres including both rural and urban areas in different parts of India showed the prevalence of bronchial asthma to be $2.05 \%$ (range: $0.4 \%-4.8 \%)^{7}$ 
Several medications are used to prevent and treat allergic manifestation. They are antihistamines, glucocorticoids, adrenaline, mast cell stabilizers and antileukotriene agents. Among these drugs, antihistaminic agents are extensively used and are the most useful in suppressing the symptoms of allergic reaction by binding to a $\mathrm{H} 1$ receptor and blocking the release of histamine by the antigen-antibody reaction. They are very safe and the most readily available over the counter drug. They are available in all forms such as tablet, syrup, cream and ointment, nasal sprays and eye drops.

The costs of medication have remarkably increased over the years. High prices of commonly used and essential medicines are a heavy burden on the government's resources as well as strain the finances of self-paying patients. Hence it is vital that we look for cost effective options to improve patient's compliance and reduce morbidity associated with the disease.

The purpose of this study was to look for the most commonly prescribed antihistamine for rational selection of medicines, and to evaluate the cost difference between the generic and branded drugs to bring out the awareness of the least costly brand in order to achieve efficiencies and better patient outcomes. Use of low cost medicine reduces health care expenditure drastically and helps patients to use financial resources in the most economical way possible.

Cost minimization analysis is the branch of pharmacoeconomics which deals with the method used to measure and compare the costs of different medical interventions. $^{8,9}$ Other branches Pharmacoeconomics include various methods of analysis such as: "cost benefit analysis (CBA), cost effectiveness analysis (CEA), cost minimization analysis (CMA), cost utility analysis (CUA), and cost of illness analysis (COI)".

In this study we selected CMA, It evaluates the cost differences between two or more medication from one group and with a similar clinical effect and then determines the least costly alternative. ${ }^{10}$ This helps in making best possible decision ensuring the maximum available benefits from every penny spent to achieve reasonable value for money.

The objective of the study was to assess the prescription pattern of antihistamine and to evaluate Cost minimization analysis of most commonly used antihistamine.

\section{METHODS}

This was a prospective observational study conducted in a tertiary care teaching hospital after getting approval from the institutional ethical committee. A total of 210 prescriptions, of both outpatients and inpatients, containing antihistamines were scrutinized after taking verbal consent from them. Various parameters like patients demographic data such as patient's age, sex, diseases to which it is given and use of generic or branded names and trends in prescribing of antihistamines were noted. The prices of the generic versions were procured from the official website www.janaushadhi.gov.in which is put up by the department of pharmaceuticals, government of India. Branded prices are noted from CIMS April- July 2016. The cost difference between the branded and generic versions evaluated. Fixed dose combinations, patients receiving syrups and injections excluded from the study. The percentage variation in the cost of the drugs was calculated using the following formula:

Percentage cost variation $=$ Price of most expensive formulation - Price of least expensive formulation / Price of least expensive formulation $\mathrm{x} 100 .^{11,12}$

\section{RESULTS}

The evaluation of prescriptions showed preponderance of female patients $(51.62 \%)$ over male (48.38\%) with allergies. The maximum patients were in between the age group of 21 to 30 years $-35.23 \%$ followed by 10 to 20 years of age $-30 \%$ and the minimum were in the age group of more than 65 years (Table-1). The commonest problem seen was allergic rhinitis followed by eczema.

Table 1: Gender wise distribution of patients.

\begin{tabular}{|ll|}
\hline Gender & Percentage $(\%)$ \\
\hline Male & 48.38 \\
\hline Female & 51.62 \\
\hline
\end{tabular}

Table 2: Distribution of total study population.

\begin{tabular}{|lll|}
\hline $\begin{array}{l}\text { Age group } \\
\text { (Years) }\end{array}$ & $\begin{array}{l}\text { No. of patients } \\
(\mathbf{n}=\mathbf{2 1 0})\end{array}$ & $\%$ of patients \\
\hline $\mathbf{1 0 - 2 0}$ & 63 & $30.00 \%$ \\
\hline $\mathbf{2 1} \mathbf{- 3 0}$ & 74 & $35.23 \%$ \\
\hline $\mathbf{3 1} \mathbf{- 4 0}$ & 41 & $19.52 \%$ \\
\hline $\mathbf{4 1 - 5 0}$ & 10 & $4.76 \%$ \\
\hline $\mathbf{5 1 - 6 0}$ & 18 & $8.57 \%$ \\
\hline$>\mathbf{6 5}$ & 4 & $1.90 \%$ \\
\hline
\end{tabular}

The costs of branded and generic versions of most commonly prescribed antihistamines in this study are shown in figures $1-4$ below. Table-1and 2 show the gender and age distribution of the patients coming to the hospital with allergic manifestations. Table-3 shows a summary of all the prescribed brands, their frequency of prescription, costs and the percentage of price difference in comparison to generic versions.

\section{DISCUSSION}

Cetrizine was the commonest antihistamine prescribed; having a generic price of Rs. 4.00. ${ }^{13}$ The commonest and costliest brand of cetrizine prescribed was cetrizine 
having a maximum retail price (MRP) of Rs. 37.50. ${ }^{14}$ Thus it was $83.75 \%$ costlier than its generic version. The range of cost difference was between $4 \%$ to $83.75 \%$ among various brands of cetrizine as compared to its generic version.

Table 3: Cost comparison of commonly prescribed antihistamines and their brands.

\begin{tabular}{|c|c|c|c|c|c|c|}
\hline Name of the drug & $\begin{array}{l}\text { No. of } \\
\text { Prescriptions }\end{array}$ & Brand name & $\begin{array}{l}\text { No. of } \\
\text { Prescriptions }\end{array}$ & $\begin{array}{l}\text { Brand } \\
\text { price in } \\
\text { rupees }\end{array}$ & $\begin{array}{l}\text { Generic } \\
\text { price in } \\
\text { rupees }\end{array}$ & $\begin{array}{l}\% \text { of cost } \\
\text { difference } \\
\text { between } \\
\text { brand and } \\
\text { generic }\end{array}$ \\
\hline $\begin{array}{l}\text { Cetrizine } \\
10 \mathrm{mg} / 10 \text { tab }\end{array}$ & 59 & $\begin{array}{l}\text { Cetzine } \\
\text { Alerid } \\
\text { Okacet } \\
\text { Cetiriz } \\
\text { Zyrtec }\end{array}$ & $\begin{array}{l}18 \\
15 \\
12 \\
9 \\
5\end{array}$ & $\begin{array}{l}37.50 \\
19.01 \\
20.00 \\
34.00 \\
19\end{array}$ & 4.0 & $\begin{array}{l}83.75 \\
37.52 \\
4 \\
75 \\
37.50\end{array}$ \\
\hline $\begin{array}{l}\text { Levocetrizine } \\
5 \mathrm{mg} / 10 \text { tab }\end{array}$ & 53 & $\begin{array}{l}\text { Levocet } \\
\text { Teczine } \\
\text { Xyzal }\end{array}$ & $\begin{array}{l}21 \\
8 \\
24 \\
\end{array}$ & $\begin{array}{l}38.50 \\
50.00 \\
65.00 \\
\end{array}$ & 4.22 & $\begin{array}{l}81.23 \\
108.48 \\
144.02 \\
\end{array}$ \\
\hline $\begin{array}{l}\text { Loratidine } \\
\text { 10mg/ } 10 \text { tabs }\end{array}$ & 19 & $\begin{array}{l}\text { Alaspan } \\
\text { Lorinol } \\
\text { Lorfast }\end{array}$ & $\begin{array}{l}8 \\
4 \\
7\end{array}$ & $\begin{array}{l}76.00 \\
41.00 \\
36.59\end{array}$ & 6.89 & $\begin{array}{l}100.30 \\
49.5 \\
43.10\end{array}$ \\
\hline $\begin{array}{l}\text { Desloratidine } \\
5 \mathrm{mg} / 10 \text { tab }\end{array}$ & 6 & $\begin{array}{l}\text { Deslor } \\
\text { Lorday }\end{array}$ & $\begin{array}{l}4 \\
2 \\
\end{array}$ & $\begin{array}{l}59 \\
47.25\end{array}$ & NA & \\
\hline $\begin{array}{l}\text { Fexofenadine } \\
120 \mathrm{mg} / 10 \text { tab }\end{array}$ & 34 & $\begin{array}{l}\text { Altiva } \\
\text { Allegra } \\
\text { Allergix }\end{array}$ & $\begin{array}{l}14 \\
16 \\
4\end{array}$ & $\begin{array}{l}99.15 \\
107.97 \\
56.67\end{array}$ & 27.79 & $\begin{array}{l}25.67 \\
28.85 \\
10.39\end{array}$ \\
\hline $\begin{array}{l}\text { Hydroxyzine } \\
25 \mathrm{mg} / 10 \text { tab }\end{array}$ & 36 & $\begin{array}{l}\text { Atarax } \\
\text { Hyrax }\end{array}$ & $\begin{array}{l}29 \\
7\end{array}$ & $\begin{array}{l}17.49 \\
30\end{array}$ & NA & \\
\hline $\begin{array}{l}\text { Mizolastine } \\
10 \mathrm{mg} / 10 \text { tab }\end{array}$ & 2 & Elina & 2 & 54.00 & NA & \\
\hline $\begin{array}{l}\text { Rupatidine } \\
\text { 10mg /10 tab }\end{array}$ & 2 & Rupahist & 2 & 45.00 & NA & \\
\hline
\end{tabular}

NA - not available on website www.janaushadhi.gov.in.

The costliest brand of levocetrizine prescribed was xyzal, having an MRP of Rs.65.00 which was $144.02 \%$ costlier than its generic version. Among fexofenadine, Allegra was the most commonly prescribed, having a price of Rs.107.97 per 10 tablets. Its branded versions were costlier by $10.39 \%$ to $28.85 \%$. Thus, the expenditure on branded medication is more than that on the generic ones. Similar studies on cost effective analysis have also shown huge difference of prices between branded and generic drugs. 15

\section{CONCLUSION}

This study demonstrated a significant price difference, ranging from $4 \%$ to $83.75 \%$ between the branded and generic version of given drugs. This in turn is leading to an increase in the cost of total treatment. As Medical Council of India has issued instructions to doctors in February 2013 to prescribe drugs by generic names as far as possible. But most of the doctors are hesitant, doubting the efficacy of generic drugs. The government of India should ensure that proper quality control measures are complied with in the manufacture of generic versions.
Assuming that proper quality control measures are complied with to retain the efficacy of the generic versions we suggest that doctors must either prescribe the generic drug or the least expensive brand to reduce the financial burden and improve in patient therapeutic outcomes and pharmacies may be issued license only if they undertake to stock generic versions of the drugs

Awareness of the problem leads to sensitization and thus resolution follows. Hope this study and others like this will help clinicians in understanding the magnitude of the issue.

Funding: No funding sources

Conflict of interest: None declared

Ethical approval: Not required

\section{REFERENCES}

1. McConnell, Thomas H. The nature of disease: Pathology for the health professions. Baltimore. Lippincott Williams and Wilkins. 2007:159.

2. Types of Allergic Diseases. NIAID. 2015:29. 
3. Anonymous. All India Coordinated Project on Aeroallergens and Human Health Report. Ministry of Environment and Forests, New Delhi; 2000.

4. Chhabra SK, Gupta CK, Chhabra P, Rajpal S. Prevalence of bronchial asthma in schoolchildren in Delhi. J Asthma. 1998;35:291-6.

5. Grammatikos AP. The genetic and environmental basis of atopic diseases. Annals of Medicine. 2008;7:482-95.

6. Viswanathan R. Definition, incidence, aetiology and natural history of asthma. Indian $\mathbf{J}$ Chest Dis. 1964;6:108-24.

7. Jindal SK, Aggarwal AN, Gupta D, Agarwal R, Kumar R, Kaur $\mathrm{T}$, et al. Indian study on epidemiology of asthma, respiratory symptoms and chronic bronchitis in adults (INSEARCH). Int $\mathrm{J}$ Tuberc Lung Dis. 2012;16:1270-7.

8. Townsend RJ. Post-marketing drug research and development. Ann Pharmacother. 1987;21:134-6.
9. Drummond M, Smith GT, Wells N. Economic Evaluation in the Development of Medicines. London: Office of Health Economics. 1988:33.

10. Newby D, Hill S. Use of pharmacoeconomics in prescribing research. Part 2: Cost-minimization analysis - when are two therapies equal? J. Clin. Pharm. Ther. 2003;28(2):145-50

11. Shankar PR, Subish P, Mishra P, Lalit M. Ambiguous pricing of Nepalese medicines. Journal of institute of medicine. 2006;28:35-38

12. Lal A, Sharma ML. A calm look at the cost of drugs in psychiatric practice. Indian $\mathrm{J}$ Psychiat. 1992;34(1):18-20.

13. Jan aushadhi. Available at: http:// janaushadhi.gov.in /about_jan_aushadhi.html. Accessed on 20 August 2016.

14. Current index of medical specialities. UBM Medica India Private Limited, Bangalore. 2016:133:492-7.

15. L.Ramesh. Economic evaluation of antibiotic prescriptions: a cost minimization analysis. J App Pharm Sci. 2013;3(06):160-3.

Cite this article as: Vaseem A, Ali M, Ali Khan MM. A study to evaluate prescribing pattern and cost minimization analysis of antihistamines among patients of allergy. Int J Basic Clin Pharmacol 2016;5:2500-3. 